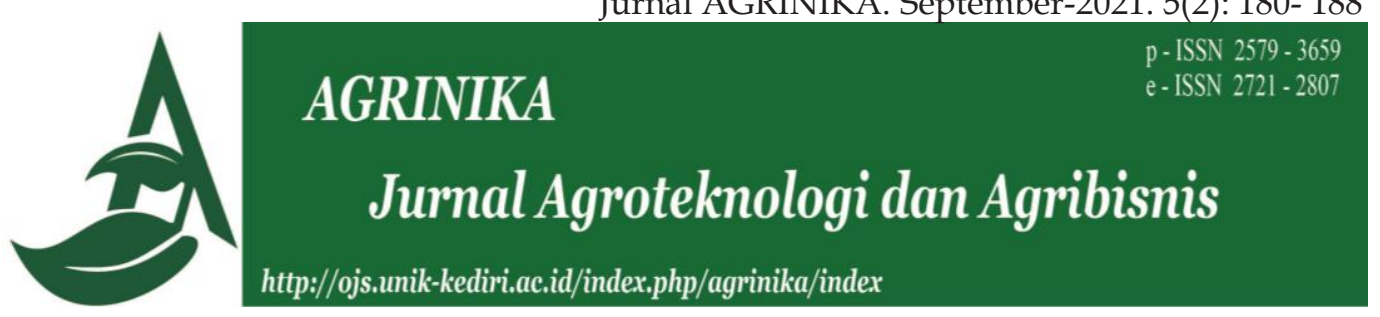

\title{
Respon Pertumbuhan dan Hasil Tanaman Bayam Merah (Amaranthus gangeticus) Pada Perlakuan Dosis Pupuk ZA
}

\author{
Edy Kustiani $^{{ }^{*}}$, Mariyono ${ }^{1}$, Bela Citra Ayuningtyas ${ }^{1}$ \\ ${ }^{11}$ Fakultas Pertanian, Universitas Kadiri, Kediri, Indonesia \\ *email: edykustiani88@unik-kediri.ac.id
}

Diterima 02 Agustus 2021/ Direvisi 08 September2021/ Disetujui 22 September 2021

\begin{abstract}
ABSTRAK
Bayam merah (Amaranthus gangeticus) termasuk sayuran penting yang disukai masyarakat karena bernilai gizi tinggi dan mudah pembudidayaannya. Upaya peningkatan hasil bayam merah salah satunya dengan pemupukan untuk menambah nutrisi yang dibutuhkan tanaman. Tujuan dari penelitian ini adalah mempelajari respon pertumbuhan dan hasil tanaman bayam merah pada perlakuan dosis pupuk ZA. Pelaksanaan penelitian ini menggunakan Rancangan Acak Lengkap (RAL) satu faktor. Faktor yang diujikan adalah dosis pupuk ZA, terdiri 6 taraf, yaitu: tanpa pupuk ZA (D0); $0.4 \mathrm{gr} /$ polybag (D1); $0.8 \mathrm{gr} /$ polybag (D2); $1.2 \mathrm{gr} /$ polybag (D3); $1.6 \mathrm{gr} /$ polybag (D4); $2 \mathrm{gr}$ /polybag (D5). Percobaan dilakukan dengan ulangan sebanyak 4 kali. Analisis data menggunakan analysis of variance (ANOVA), apabila berbeda nyata dilanjutkan uji Beda Nyata Terkecil (BNT) taraf $5 \%$. Perlakuan dosis pupuk ZA berpengaruh nyata terhadap pertumbuhan dan hasil tanaman bayam merah. Perlakuan dosis pupuk ZA $1.2 \mathrm{gr} /$ polybag (D3) menghasilkan tinggi, jumlah dan luas daun tanaman bayam merah tertinggi pada pengamatan umur 14, 21, dan $28 \mathrm{HST}$. Dosis pupuk ZA $1.2 \mathrm{gr} /$ polybag (D3) juga menunjukkan berat basah dan berat kering tanaman tertinggi sebesar 49.15 dan 4.38 gram. Dosis ZA $1.2 \mathrm{gr} /$ polybag merupakan dosis ideal untuk meningkatkan produktivitas tanaman bayam merah.
\end{abstract}

Kata kunci: Bayam merah; Dosis; Pertumbuhan; Produksi

\begin{abstract}
Red spinach (Amaranthus gangeticus) is one of the most popular vegetables because of its high nutritional value and easy cultivation. Efforts to increase the production of red spinach are to fertilize to meet the needs of both macro and micronutrients. This study aimed to determine the effect of ZA fertilizer dose on the growth and yield of red spinach. The environmental design used was a non-factorial, completely randomized design with four replications. The factors tested were the dose of ZA fertilizer which consisted of 6 levels, namely: without ZA fertilizer (D0); $0.4 \mathrm{gr} /$ polybag (D1); $0.8 \mathrm{gr} /$ polybag (D2); 1.2 $\mathrm{gr} /$ polybag (D3); $1.6 \mathrm{gr} /$ polybag (D4); $2 \mathrm{gr} /$ polybag (D5). The data obtained were analyzed using analysis of variance, and if the results were significantly different, the BNT test was continued at a $5 \%$ level. The growth and yield of red spinach showed significant differences due to the ZA fertilizer dose treatment. The ZA fertilizer dose treatment of 1.2 $\mathrm{g} /$ polybag (D3) resulted in the highest plant height, the number of leaves, and leaf area of red spinach at 14, 21, and 28 days after planting. The ZA fertilizer dose treatment of 1.2 g/polybag (D3) resulted in the highest wet and dry weight plants of 49.15 and 4.38 grams, respectively. The ZA $1.2 \mathrm{gr} /$ polybag dose is the ideal dose to increase the productivity of red spinach.
\end{abstract}

Keywords: Dose; Growth; Production; Red spinach 


\section{PENDAHULUAN}

Tanaman hortikultura yang masuk dalam family Amarantaceae, salah satunya adalah bayam merah (Amaranthus gangeticus). Bayam merah bernilai gizi tinggi karena mengandung beberapa unsur penting yaitu: garam mineral, protein, vitamin $A$, vitamin $C$, antioksidan polifenol (Pebrianti et al., 2015), sedikit vitamin B dan pigmen antosianin (Rukmana, 2008). Bayam sebagai sayuran penting berperan dalam menurunkan tekanan darah dan kolesterol yang tinggi, melancarkan peredaran darah (MARDHIANA et al., 2017), serta mencegah pembentukan radikal bebas karena mengandung antosianin (Lingga, 2010).

Kesadaran masyarakat yang semakin meningkat akan manfaat dan pentingnya sayuran bagi kesehatan menyebabkan kebutuhan sayur-sayuran terus meningkat setiap tahunnya, tidak terkecuali bayam merah. Peluang pengembangan bayam merah baik dari budidaya maupun pengolahannya cukup bagus karena bayam merah bernilai ekonomis cukup tinggi dibandingkan jenis bayam lainnya. Dalam budidaya tanaman, keberadaan dan ketersediaan nutrisi tanah sangat penting. Nutrisi yang tersedia sangat berguna untuk proses metabolisme dalam pertumbuhan dan perkembangan tanaman sehingga produksi maksimal. Kebutuhan unsur hara meningkat seiring bertambahnya umur tanaman (Qibtiah et al., 2016).

Dalam budidaya tanaman bayam merah perlu diperhatikan media tanam. Tanah yang baik sebagai media tanam harus mengandung nutrisi yang dibutuhkan tanaman untuk meningkatkan pertumbuhannya. Salah satu upaya peningkatan unsur hara dalam tanah agar produksi bayam merah tinggi adalah dengan pemupukan (Kesuma \& Salamah, 2013).

Pupuk ZA atau amonium sulfat $(\mathrm{NH} 4)_{2} \mathrm{SO} 4$ merupakan pupuk anorganik tunggal yang mengandung unsur nitrogen $(\mathrm{N})$ sebesar $21 \%$ dan sulfat $(\mathrm{S})$ sebesar 23\% (Elisabeth et al., 2013). Unsur nitrogen dan sulfat pada pupuk ZA termasuk unsur makro yang dibutuhkan tanaman untuk pertumbuhannya. Unsur nitrogen berguna dalam pembelahan dan perkembangan sel sedangkan unsur sulfur sebagai nutrisi dalam proses fotosintesis (Novizan, 2001).

Penggunaan pupuk ZA (ammonium sulfat) pada budidaya tanaman biasanya untuk menggantikan pupuk urea karena kandungan nitrogen cukup tinggi dan harganya relatif murah daripada pupuk urea (Suminar et al., 2017). Senyawa dasar pada pupuk ZA adalah ammonium sedangkan pupuk urea adalah amida. Pupuk anorganik yang mengandung unsur nitrogen biasanya mempunyai pergerakan tinggi dalam floem maupun tanah. Biasanya saat pemupukan urea juga ditambahkan pupuk ZA untuk mengurangi kehilangan unsur nitrogen. Pupuk ZA yang diberikan ke tanah mampu mengikat nitrogen sehingga dapat diserap akar tanaman (Sumbayak et al., 2018).

Aplikasi pupuk ZA dalam budidaya tanaman menghasilkan bobot kering lebih tinggi dibandingkan penggunaan pupuk urea (Sumbayak et al., 2018), dan pada budidaya tanaman bawang merah dapat meningkatkan berat segar dan kering umbi serta berat segar tanaman (Santosa et al., 2020).

Pemupukan dalam budidaya tanaman harus memperhitungkan dosis yang tepat untuk menghindari keracunan atau defisiensi unsur hara 
dalam tanaman. Dosis masing-masing pupuk yang digunakan bervariasi tergantung dari varietas, iklim, jarak tanam, jenis pupuk. (Suwandi et al., 2016). Berdasarkan latar belakang diatas, penting dilakukan percobaan untuk mempelajari respon pertumbuhan dan hasil tanaman bayam merah pada perlakuan dosis pupuk ZA.

\section{.BAHAN DAN METODE}

Percobaan telah dilakukan mulai bulan Januari hingga Februari 2020 di kebun percobaan Fakultas Pertanian Universitas Kadiri Kota Kediri. Pada penelitian ini menggunakan Rancangan lingkungan yaitu Rancangan Acak Lengkap (RAL) satu faktor. Faktor yang diujikan yaitu dosis pupuk ZA dengan 6 level dan diulang 4 kali. Dosis pupuk ZA terdiri dari: tanpa pupuk ZA (D0); 0.4 gr/polybag (D1); 0.8 gr/polybag (D2); 1.2 gr/polybag (D3); 1.6 gr/polybag (D4); 2 gr/polybag (D5).

Kegiatan dalam penelitian ini adalah pembuatan media tanam, persemaian, penanaman, pemupukan, penyiraman, penyulaman, pengendalian hama penyakit dan panen. Persiapan media tanam adalah mengisi $3 / 4$ polybag dengan campuran tanah dan kompos. Persemaian dilakukan pada wadah plastik yang berisi tanah dan pupuk kandang. Setelah persemaian siap, benih bayam merah ditaburkan dan ditutup kembali dengan tanah sekitar 0,5 cm. Pemindahan bibit ke media tanam dilakukan pada umur 12 hari dengan tinggi kurang lebih $4 \mathrm{~cm}$. Penyiraman dilakukan setiap hari disesuaikan kebutuhan. Apabila ada tanaman yang mati dilakukan penyulaman. Dalam pemupukan berdasarkan dosis pupuk ZA yang diujikan saat tanaman bayam merah $\begin{array}{lllll}\text { berumur } 7 & \text { HST dan } 20 & \text { HST. }\end{array}$
Pemupukan dilakukan dengan menaburkan pupuk sekitar $5 \mathrm{~cm}$ dari batang tanaman. Setelah pemupukan dilakukan penyiraman. Pengendalian hama penyakit dilakukan apabila terdapat hama yang menyerang. Panen bayam merah pada saat tanaman berumur 28 HSy dengan kurang lebih 20-30 cm.

Variabel pengamatan dalam penelitian ini adalah berat basah dan berat kering tanaman, luas daun, jumlah daun, serta tinggi tanaman. Pengamatan luas dan jumlah daun, serta tinggi tanaman bayam merah dilakukan saat umur 7, 14, 21 dan 28 HST, sedangkan pengamatan produksi tanaman baik berat basah dan berat kering tanaman pada saat panen. Tinggi tanaman diukur mulai dari permukaan tanah sampai titik tumbuh paling atas. Penghitungan daun adalah daun yang membuka sempurna. Pengukuran luas daun pada penelitian ini menggunakan metode panjang $\mathrm{x}$ lebar $\mathrm{x}$ konstanta (PxLxK). Tanaman bayam setelah dipanen dan dibersihkan dari tanah kemudian ditimbang sebagai berat basah tanaman. Pengeringan tanaman bayam merah menggunakan oven pada suhu $80^{\circ} \mathrm{C}$ selama 24 jam. Hasil penimbangan tanaman yang sudah dikeringkan sebagai berat kering tanaman. Analisis data yang digunakan adalah Anova, bila berbeda nyata diuji lanjut dengan uji Beda Nyata Terkecil (BNT) taraf 5\%.

\section{HASIL DAN PEMBAHASAN}

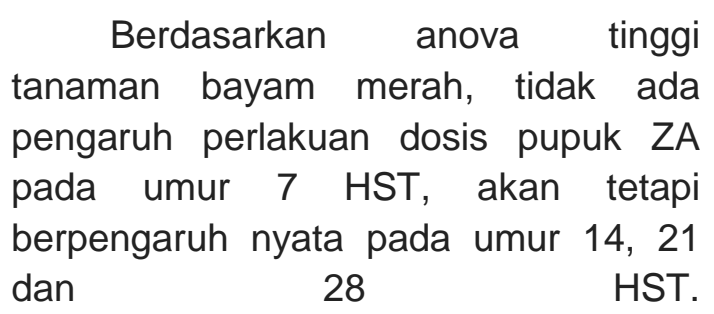


Tinggi tanaman bayam merah umur 7 HST tidak berbeda nyata antar perlakuan disebabkan karena unsur hara terutama nitrogen dalam tanah tersebut masih cukup untuk pertumbuhan tanaman. Pengamatan tanaman bayam merah pada umur 14, 21, dan 28 HST menghasilkan tinggi tanaman tertinggi dengan dosis pupuk ZA 1,2 gr/polybag (perlakuan D3) masing-masing sebesar 11,88; 18,76 dan 29,50 cm. Dosis pupuk ZA 1.2 gr/polybag merupakan dosis yang ideal untuk penambahan tinggi tanaman bayam merah. Peningkatan tinggi tanaman menunjukkan semakin bertambahnya jumlah dan ukuran sel serta pembentukan jaringan yang akan mempengaruhi pertumbuhan batang, daun dan sistem perakaran tanaman. Aktivitas pembentukan xylem meningkat dan sel-sel yang tumbuh semakin membesar menyebabkan kambium terdorong keluar dan membentuk sel-sel baru di luar lapisan. Hal inilah yang menyebabkan peningkatan tinggi tanaman (Wasonowati, 2011).

Tabel 1. Rata-rata tinggi tanaman bayam merah pada perlakuan dosis pupuk ZA

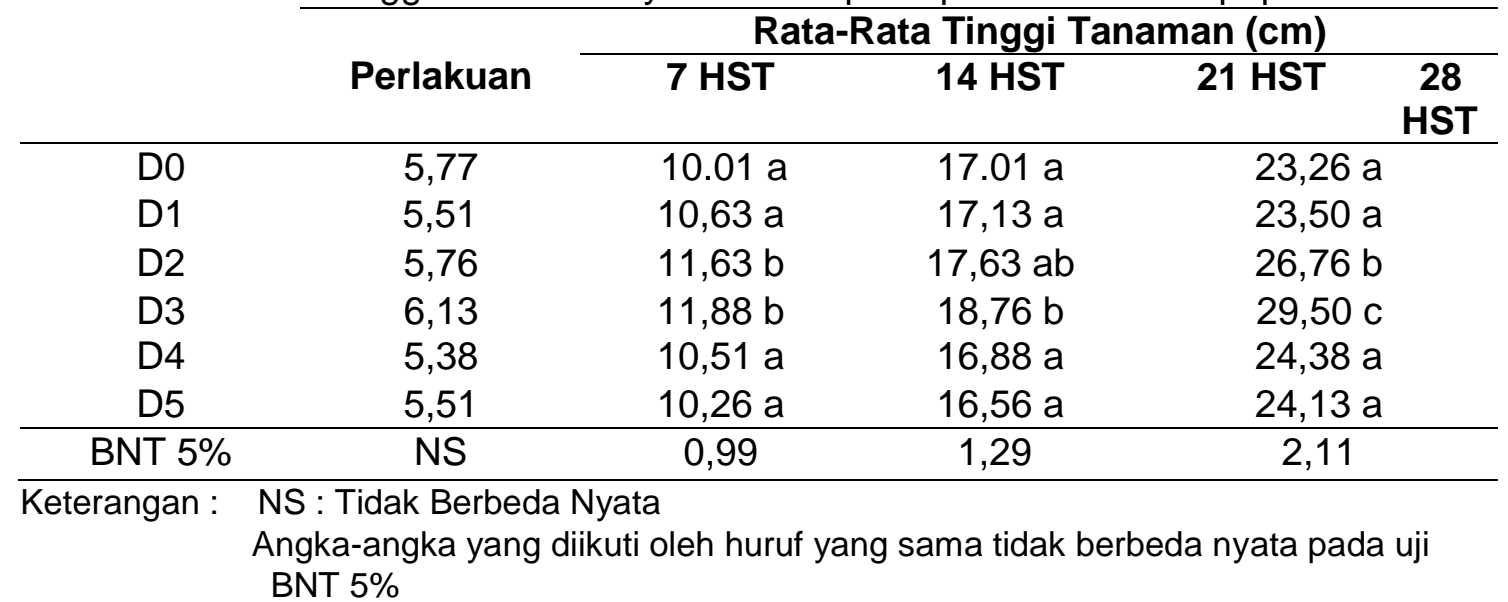

Analisis sidik ragam jumlah daun tanaman bayam merah adalah tidak ada pengaruh dosis pupuk ZA pada umur 7 HST antar perlakuan. Hal ini dimungkinkan karena kebutuhan unsur hara untuk pertumbuhan maksimal umur 7 HST pada tanaman bayam merah masih tercukupi oleh media tanam dengan tanpa pemupukan. Jumlah daun tanaman bayam merah berbeda nyata karena perlakuan dosis pupuk ZA pada umur 14, 21 dan 28 HST. Kebutuhan unsur hara tanaman meningkat seiring meningkatnya umur tanaman karena untuk pertumbuhan vegetatif sehingga terjadi beda nyata dengan adanya perlakuan dosis pupuk ZA. Pada umur 14, 21 dan 28 HST perlakuan dosis pupuk ZA 1.2 cc/polybag menghasilkan jumlah daun tanaman bayam merah tertinggi masingmasing sebesar 5,88; 9,38 dan 10,51 helai/tanaman. Pupuk ZA pada dosis 1.2 cc/polybag sebagai dosis optimal untuk pertumbuhan vegetative dibandingkan dosis pupuk ZA lainnya.

Banyak sedikitnya jumlah daun yang terbentuk juga dipengaruhi keberadaan unsur hara atau nutrisi dalam tanah. Pada tanah yang kekurangan atau ketidakadaan unsur nitrogen menyebabkan penuaan pada daun (Maillard et al., 2015).

Pada pembentukan daun tumbuhan juga dipengaruhi oleh interval waktu yang teratur untuk menghasilkan 
daun baru (plastochron) dan pemunculan fitokhrom. Apabila interval waktu yang dibutuhkan untuk menghasilkan daun baru semakin cepat maka daun yang terbentuk akan semakin banyak. Salah satu faktor yang mempengaruhi munculnya plastochron dan fitokhrom adalah tersedianya nitrogen. Sumber nitrogen berasal dari tanah atau pupuk yang diberikan ke tanaman.

Tabel 2. Rata-rata jumlah daun tanaman bayam merah pada perlakuan dosis pupuk ZA

\begin{tabular}{ccccc}
\hline \multirow{2}{*}{ Perlakuan } & \multicolumn{4}{c}{ Rata-Rata Jumlah Daun (Helai) } \\
\cline { 2 - 5 } & $\mathbf{7 ~ H S T}$ & $\mathbf{1 4} \mathbf{~ H S T}$ & $\mathbf{2 1 ~ H S T}$ & $\mathbf{2 8} \mathbf{H S T}$ \\
\hline D0 & 3,76 & $5,63 \mathrm{ab}$ & $8.01 \mathrm{a}$ & $8,88 \mathrm{a}$ \\
D1 & 3,62 & $5,63 \mathrm{ab}$ & $8,76 \mathrm{~b}$ & $9,26 \mathrm{ab}$ \\
D2 & 3,76 & $5,76 \mathrm{~b}$ & $9.01 \mathrm{~b}$ & $10.01 \mathrm{~b}$ \\
D3 & 3,76 & $5,88 \mathrm{~b}$ & $9,38 \mathrm{~b}$ & $10,51 \mathrm{~b}$ \\
D4 & 3,61 & $5,13 \mathrm{a}$ & $8,38 \mathrm{ab}$ & $9,38 \mathrm{ab}$ \\
D5 & 3,51 & $5,26 \mathrm{ab}$ & $8,13 \mathrm{ab}$ & $9.01 \mathrm{a}$ \\
\hline BNT 5\% & NS & 0,51 & 0,66 & 0,87 \\
\hline Keterangan : NS : Tidak Berbeda Nyata \\
Angka-angka yang diikuti oleh huruf yang sama tidak berbeda nyata pada uji \\
BNT 5\%
\end{tabular}

Besarnya proses fotosintesis ditentukan dari luas daun. Daun tempat berlangsungnya proses fotosintesis dimungkinkan daun yang semakin luas berpengaruh pada peningkatan proses fotosintesis. Dari pengamatan luas daun juga bisa digunakan untuk menentukan kandungan klorofil suatu tanaman. Daun yang mempunyai permukaan lebih luas menunjukkan kandungan klorofilnya semakin banyak (Wijaya et al., 2020).

Perlakuan dosis pupuk ZA pada umur 7 HST tidak memberikan pengaruh yang nyata terhadap luas daun tanaman bayam merah, sedangkan pengaruh nyata terjadi pada umur 14, 21 dan 28 HST. Pemberian pupuk ZA pada awal pertumbuhan (umur 7 HST) tidak berbeda antar perlakuan karena kebutuhan nitrogen untuk pertumbuhan tanaman yang maksimal masih tercukupi oleh nutrisi yang tersedia dalam tanah.

Proses metabolism pada tanaman berjalan dengan baik apabila kecukupan nutrisi dan cahaya sehingga pertumbuhan tanaman maksimal. Kuantitas penyerapan cahaya juga dipengaruhi luas daun. Penyerapan cahaya yang mencukupi mampu memaksimalkan proses fotosintesis sehingga laju pertumbuhan akan meningkat (Setyanti et al., 2013).

Dosis pupuk ZA berpengaruh nyata terhadap luas daun tanaman bayam merah pada pengamatan umur 14, 21 dan 28 HST. Perlakuan dosis pupuk ZA 1.2 gram/tanaman (D3) menghasilkan luas daun tanaman bayam merah tertinggi pada umur 14 , 21, 28 HST masing-masing sebesar 26.96, 117.82, dan $173.35 \mathrm{~cm}^{2}$. Pada dosis pupuk ZA 1.2 gram/polybag merupakan dosis dimana kebutuhan unsur nitrogen sesuai dengan kebutuhan tanaman bayam merah dalam membentuk luas daun sedangkan pada dosis 1.6 gram/polybag (D4) dan 2.0/polybag (D5) merupakan dosis yang berlebih (over dosis). 
Tanaman yang cukup mendapatkan unsur nitrogen helaian daun yang lebih luas dan mengandung klorofil lebih tinggi. Semakin luas daun yang terbentuk proses fotosintesis semakin meningkat sehingga semakin banyak karbohidrat yang dihasilkan untuk meningkatkan pertumbuhan tanaman (Wijaya et al., 2020). Helaian daun yang luas bisa untuk menentukan kecepatan pertumbuhan suatu tanaman, dimana semakin luas daun maka pertumbuhannya semakin meningkat (cepat).

Pemupukan yang mengandung unsur $\mathrm{N}$ dapat meningkatkan penyerapan cahaya matahari dan pertumbuhan di daun. Hal ini menyebabkan laju fotosintesis meningkat dan pendistribusian hasil fotosintesis ke biji juga meningkat (Napitupulu \& Winarto, 2010).

Tabel 3. Rata-rata luas daun tanaman bayam merah pada perlakuan dosis pupuk ZA

\begin{tabular}{ccccc}
\hline \multirow{2}{*}{ Perlakuan } & \multicolumn{4}{c}{ Rata-Rata Luas Daun $\left.\mathbf{( c m}^{\mathbf{2}}\right)$} \\
\cline { 2 - 5 } & $\mathbf{7 ~ H S T}$ & $\mathbf{1 4} \mathbf{H S T}$ & $\mathbf{2 1} \mathbf{H S T}$ & $\mathbf{2 8} \mathbf{H S T}$ \\
\hline D0 & 3,87 & $24,81 \mathrm{~b}$ & $98,44 \mathrm{ab}$ & $116,32 \mathrm{a}$ \\
D1 & 3,48 & $22,36 \mathrm{~b}$ & $87,79 \mathrm{a}$ & $117,99 \mathrm{a}$ \\
D2 & 3,87 & $25,68 \mathrm{~b}$ & $105,98 \mathrm{ab}$ & $149,27 \mathrm{~b}$ \\
D3 & 4,64 & $26,96 \mathrm{~b}$ & $117,82 \mathrm{~b}$ & $173,35 \mathrm{~b}$ \\
D4 & 4,29 & $17,59 \mathrm{ab}$ & $73,56 \mathrm{a}$ & $118,63 \mathrm{a}$ \\
D5 & 3,48 & $16,33 \mathrm{a}$ & $76,13 \mathrm{a}$ & $116,32 \mathrm{a}$ \\
\hline BNT 5\% & Ns & 5,66 & 20,57 & 24,36 \\
\hline
\end{tabular}

Keterangan : NS : Tidak Berbeda Nyata

Angka-angka yang diikuti oleh huruf yang sama tidak berbeda nyata pada uji BNT 5\%

Tanaman dalam menghasilkan berat basah yang maksimal membutuhkan energi dan unsur hara untuk menambah jumlah dan ukuran sel serta kandungan air dalam tanaman. Berat basah tumbuhan dipengaruhi kandungan air dalam tubuhnya. Tanaman setelah dipanen dan dibersihkan dari tanah kemudian ditimbang sebagai berat basah tanaman.

Pada saat panen semua bagian tanaman pada masing-masing polybang dibersihkan kemudian ditimbang sebagai berat basah tanaman per polybag. Berdasarkan hasil analisis ragam, dosis pupuk ZA 1.2 gram/polybag (D3) berpengaruh nyata terhadap berat basah tanaman. Berat basah tanaman bayam merah tertinggi pada perlakuan dosis pupuk ZA 1.2 gram/polybag (D3) sebesar 49.15 gram/tanaman. Adanya korelasi antara variabel pertumbuhan tanaman bayam merah yang meliputi tinggi tanaman, jumlah daun dan luas daun dengan berat basah tanaman. Tanaman bayam merah yang pertumbuhannya baik akan menghasilkan berat basah tanaman yang tinggi pula.

Tabel 4. Rata-rata berat basah tanaman bayam merah pada perlakuan dosis pupuk ZA

\begin{tabular}{cc}
\hline Perlakuan & Rata-Rata Berat Basah (g/tan) \\
\hline D0 & $31,52 \mathrm{a}$ \\
D1 & $35,27 \mathrm{ab}$ \\
D2 & $41,72 \mathrm{~b}$ \\
D3 & $49,15 \mathrm{~b}$
\end{tabular}




\begin{tabular}{cc} 
D4 & $36,48 \mathrm{ab}$ \\
\hline D5 & $34,09 \mathrm{ab}$ \\
\hline BNT 5\% & 9,18 \\
\hline $\begin{array}{c}\text { Keterangan : Angka-angka yang diikuti oleh huruf yang sama tidak berbeda nyata pada uji } \\
\text { BNT }\end{array}$
\end{tabular}

Analisis sidik ragam perlakuan dosis $1.2 \mathrm{gram} /$ polybag menunjukkan pengaruh yang nyata terhadap berat kering tanaman bayam merah pada pengamatan 28 HST. Dari data di atas menunjukkan bahwa berat kering terbanyak terdapat pada perlakuan dosis 1.2 gram/polybag (D3) yaitu 4.37 gram, sedangkan berat kering paling sedikit terdapat pada perlakuan D0 tanpa perlakuan dengan berat 2.32 gram. Berat kering tanaman bayam merah merupakan tanaman bayam merah yang sudah dikeringkan dan didalamnya sudah tidak ada lagi kadar air. Menurut (Salisbury, 1995), unsur hara (nutrisi) yang diserap tanaman dari lingkungan akan berpengaruh terhadap pertumbuhan dan produksinya.

Tabel 5. Rata-rata berat kering tanaman bayam merah pada perlakuan dosis pupuk ZA

\begin{tabular}{cc}
\hline Perlakuan & Rata-Rata Berat Kering (g/tan) \\
\hline D0 & $2,33 \mathrm{a}$ \\
D1 & $2,61 \mathrm{a}$ \\
D2 & $3,18 \mathrm{a}$ \\
D3 & $4,38 \mathrm{~b}$ \\
D4 & $2,74 \mathrm{a}$ \\
D5 & $2,48 \mathrm{a}$ \\
\hline BNT 5\% & 0,89
\end{tabular}

Keterangan : Angka-angka yang diikuti oleh huruf yang sama tidak berbeda nyata pada uji BNT $5 \%$

Berat basah tanaman yang dikurangi air sebagai berat kering tanaman. Pertumbuhan vegetative berpengaruh terhadap berat kering tanaman, dimana pertumbuhan vegetatif yang baik akan diiringi dengan peningkatan berat kering tanaman (Annisa et al., 2018). Pada tanaman bawang merah dengan pemberian pupuk ZA berpengaruh nyata terhadap produksi, jumlah daun dan tinggi tanaman (Saptorini et al., 2019).

Unsur nitrogen yang diberikan pada tanaman berguna untuk peningkatan pertumbuhan dan produksinya. Akan tetapi pemberian unsur nitrogen yang berlebihan akan menimbulkan tekanan pada tanaman tersebut. Hal ini karena tanaman bayam merah bersifat sukulen dan mudah terserang hama penyakit. Berdasarkan (Senoaji \& Praptana, 2015), pemberian unsur nitrogen dengan dosis tinggi menyebabkan melemahnya jaringan tanaman sehingga tanaman peka terhadap hama penyakit.

\section{KESIMPULAN}

Adanya peningkatan pertumbuhan dan hasil tanmaan bayam merah karena perlakuan dosis pupuk ZA. inggi tanaman, jumlah daun dan luas daun menunjukkan hasil tertinggi pada perlakuan dosis pupuk ZA 1.2 gr/polybag (D3) saat umur 14, 21 dan 28 HST. Perlakuan dosis pupuk ZA 1.2 gr/polybag (D3) menunjukkan berat basah dan berat kering tanaman 
tertinggi masing-masing sebesar 49.15 dan $4.38 \mathrm{gram}$. Dosis ZA $1.2 \mathrm{gr} / \mathrm{polybag}$ merupakan dosis ideal dalam meningkatkan pertumbuhan dan hasil tanaman bayam merah.

\section{UCAPAN TERIMAKASIH}

Penulis mengucapkan terima kasih kepada LP3M Universitas Kadiri dan Dosen-dosen Fakultas Pertanian yang telah memberikan dukungan moril dan material saat penelitian maupun penyusunan naskah jurnal.

\section{DAFTAR PUSTAKA}

Annisa, D. ., Darmawati, A., \& Sumarsono. (2018). Pertumbuhan dan produksi bayam merah (Amaranthus tricolor L.) dengan pemberian pupuk kandang dan giberelin. J. Agro Complex, 2(2), 102-108.

https://doi.org/https://doi.org/10.147 10/joac.2.2.102-108

Elisabeth, D. W., Santoso, M., \& Herlina, N. (2013). Pengaruh Pemberian berbagai Komposisi Bahan Organik pada Pertumbuhan dan Hasil Tanaman Bawang Merah (Allium ascalonicum L.). Jurnal Produksi Tanaman.

Kesuma, P., \& Salamah, Z. (2013). Pertumbuhan Tanaman Bayam Cabut (Amaranthus tricolor L.) Dengan Pemberian Kompos Berbahan Dasar Daun Krinyu (Chromolaena odorata L.). JURNAL BIOEDUKATIKA. https://doi.org/10.26555/bioedukati ka.v1i1.4080

Lingga, L. (2010). Cerdas Memilih Sayuran. PT. Agro Media Pustaka.

Maillard, A., Diquélou, S., Billard, V.,
Laîné, P., Garnica, M., Prudent, M., Garcia-Mina, J. M., Yvin, J. C., \& Ourry, A. (2015). Leaf mineral nutrient remobilization during leaf senescence and modulation by nutrient deficiency. Frontiers in Plant Science. https://doi.org/10.3389/fpls.2015.00 317

MARDHIANA, M., PRADANA, A. P., ADIWENA, M., KARTINA, K., SANTOSO, D., WIJAYA, R., \& MALIKI, A. (2017). Effects of pruning on growth and yield of cucumber (Cucumis sativus) Mercy variety in The acid soil of North Kalimantan, Indonesia. Cell Biology and Development. https://doi.org/10.13057/cellbioldev/ v010103

Napitupulu, D., \& Winarto, L. (2010). Pengaruh Pemberian Pupuk N Dan K Terhadap Pertumbuhan Dan Produksi Bawang Merah. Jurnal Hortikultura.

https://doi.org/10.21082/jhort.v20n1 .2010.p

Novizan. (2001). Petunjuk Pemupukan yang Efektif. AgroMedia, Jakarta.

Pebrianti, C., Ainurrasyid, R. B., Purnamaningsih, L., Leaf, R., \& Merah, B. (2015). Uji Kadar Antosianin Dan Hasil Enam Varietas Tanaman Bayam Merah ( Alternanthera Amoena Voss ) Pada Musim Hujan. Jurnal Produksi Tanaman.

Qibtiah, M., Pertanian, F., \& Pertanian, D. F. (2016). Pertumbuhan dan Hasil Tanaman Bawang Daun ( Allium fistulosum $\mathrm{L}$.) Pada Pemotongan Bibit Anakan dan 
Pemberian Pupuk Kandang Sapi AGRIFOR.

Rukmana, R. (2008). Bayam, Bertanam dan Pengolahan Pascapanen. Kanisius, Yogyakarta.

Salisbury, F. (1995). Fisiologi Tumbuhan. In Fisiologi Tumbuhan.

Santosa, S. L., Rai, I. N., \& Diara, W. (2020). Pengaruh Pupuk Za Dan Kompos Terhadap Kandungan $\mathrm{Pb}$, Zn, Cu dan N Tanah Serta Hasil Tanaman Pada Sistem Budidaya Bawang Merah Di Tepi Danau Batur, Kintamani, Bangli. ECOTROPHIC: Jurnal IImu Lingkungan (Journal of Environmental Science). https://doi.org/10.24843/ejes.2020. v14.i02.p03

Saptorini, Supandji, \& Taufik. (2019). Pengujian pemberian pupuk za terhadap pertumbuhan dan produksi tanaman bawang merah varietas bauji. Agrinika, 3(2), 7681.

Senoaji, \& Praptana, H. (2015). Interaksi Nitrogen dengan Insidensi Penyakit Tungro dan Pengedaliannya Secara Terpadu pada Tanaman Padi. Iptek Tanaman Pangan, 8(2), 80-89.

Setyanti, Y. H., Anwar, S., \& Slamet, W. (2013). Karakteristik fotosintetik dan serapan fosfor hijauan alfalfa (Medicago sativa) pada tinggi pemotongan dan pemupukan nitrogen yang berbeda. Animal Agriculture Journal.

Sumbayak, E. R. M., Sunaryo, \& Widaryanto, E. (2018). Pengaruh
Dengan Sistem Vertikultur. Jurnal kombinasi dosis pupuk Urea dan ZA terhadap pertumbuhan dan hasil tanaman kailan (Brassica oleraceae var. Alboglabra). Jurnal Produksi Tanaman.

Suminar, R., Suwarto, ., \& Purnamawati, H. (2017). Penentuan Dosis Optimum Pemupukan N, P, dan K pada Sorgum (Sorghum bicolor [L.] Moench). Jurnal IImu Pertanian Indonesia.

Suwandi, S., Sopha, G. A., \& Yufdy, M. P. (2016). Efektivitas Pengelolaan Pupuk Organik, NPK, dan Pupuk Hayati terhadap Pertumbuhan dan Hasil Bawang Merah. Jurnal Hortikultura.

https://doi.org/10.21082/jhort.v25n3 .2015.p208-221

Wasonowati, C. (2011). Meningkatkan Pertumbuhan Tanaman Tomat (Lycopersicon esculentum) Dengan Sistem Budidaya Hidroponik. Agrovigor.

Wijaya, R., Hariono, B., \& Saputra, T. W. (2020). Pengaruh Kadar Nutrisi dan Media Tanam Terhadap Pertumbuhan Bayam Merah (Alternanthera amoena voss) Sistem Hidroponik. Jurnal IImiah Inovasi. https://doi.org/10.25047/jii.v20i1.19 29 